WellBeing International

WBI Studies Repository

$5-2005$

\title{
Range Expansion by Moose into Coastal Temperate Rainforests of British Columbia, Canada
}

C. T. Darimont

University of Victoria

P. C. Paquet

University of Calgary

T. E. Reimchen

University of Victoria

V. Crichton

Manitoba Conservation, Wildlife and Ecosystem Protection Branch

Follow this and additional works at: https://www.wellbeingintlstudiesrepository.org/bioeopp

Part of the Animal Studies Commons, Population Biology Commons, and the Terrestrial and Aquatic Ecology Commons

\section{Recommended Citation}

Darimont, C. T., Paquet, P. C., Reimchen, T. E., \& Crichton, V. (2005). Range expansion by moose into coastal temperate rainforests of British Columbia, Canada. Diversity and Distributions, 11(3), 235-239.

This material is brought to you for free and open access by WellBeing International. It has been accepted for inclusion by an authorized administrator of the WBI Studies Repository. For more information, please contact wbisr-info@wellbeingintl.org.

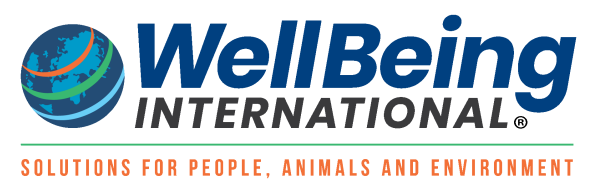




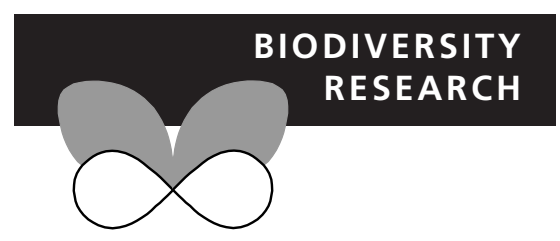

\title{
Range expansion by moose into coastal temperate rainforests of British Columbia, Canada
}

\author{
C. T. Darimont ${ }^{1,2 *}$, P. C. Paquet ${ }^{2,3}$, T. E. Reimchen ${ }^{1}$ and V. Crichton ${ }^{4}$
}

\begin{abstract}
${ }^{1}$ Department of Biology, PO Box 3020, Stn CSC. University of Victoria, Victoria, B.C. Canada V8W3 N5.E-mail: cdarimon@uvic.ca; ${ }^{2}$ Raincoast Conservation Society. PO Box 26. Bella Bella, B.C. Canada, VOT 1B0; ${ }^{3}$ Faculty of Environmental Design, University of Calgary, Calgary, Alberta, Canada, T2N 1 N4; ${ }^{4}$ Manitoba Conservation, Wildlife and Ecosystem Protection Branch, Box 24, 200 Saulteaux Crescent, Winnipeg, Manitoba Canada R3J 3 W3
\end{abstract}

${ }^{*}$ Correspondence: Chris Darimont, Department of Biology, PO Box 3020, Stn. CSC, University of Victoria, Victoria, British Columbia, Canada, V8W 3 N5. Tel.: (250) 7217125 , Fax.: (250) 721 7120,E-mail: cdarimon@uvic.ca

\begin{abstract}
Ranges of species are dynamic and respond to long-term climate change and contemporary effects such as habitat modification. We report here that moose (Alces alces) have recently colonized coastal temperate rainforests of British Columbia, Canada. Contrary to recent publications, field observations of moose and their sign, combined with their occurrence in wolf (Canis lupus) faeces, suggest that moose are now widespread on the coastal mainland and occur on least three islands. Traditional ecological knowledge (information accumulated by aboriginal peoples about their environment) suggests that colonization occurred during the mid 1900s, concomitant with logging of major watersheds that bisect the Coast Mountain Range. Range expansion by moose may have ecological consequences such as alteration of predatorprey dynamics and transmission of disease to native deer (Odocoileus hemionus).
\end{abstract}

\section{Keywords}

Alces alces, British Columbia, coastal temperate rainforest, Canis lupus, distribution, range expansion, traditional ecological knowledge.

\section{INTRODUCTION}

Mammalian distributions during the Pleistocene and Holocene have been dynamic, responding to climate and other environmental variability over time (Lyons, 2003). Ranges of species continue to expand or contract, often rapidly, in part due to anthropogenic effects such as landscape modification, global warming, persecution by humans, and introduction of exotics (Sih et al., 2000; Parmesan \& Yohe, 2003; Laliberte \& Ripple, 2004; Oden et al., 2004). Changes in species' distributions can alter important ecological interactions, including disease, competition, herbivory, and predation (Vermeij, 1991). In the case of wildlife species that are commonly hunted by humans, range contractions or expansions may also have economic, management, and safety implications.

Moose (Alces alces) are a circumpolar mammal undergoing worldwide expansion since the late Pleistocene, largely mediated by climate change (Lister, 1993). There is no palaeontological evidence for their presence in North America before the late Wisconsinian (Kurtén \& Anderson, 1980). Recent genetic data suggest that moose colonized North America less than 15,000 years ago (Hundertmark et al., 2002). Since then, their range boundaries were constrained by limitations imposed by climate and vegetation, which changed over time (Karns, 1998). In recent decades, however, moose of North America have expanded into areas considered previously unoccupied (Telfer, 1984; Karns, 1998). Similar range expansions (or contractions) have not been reported in Eurasia to our knowledge. In North America, vegetation and snow cover are thought to restrict northern distribution, whereas a hot climate may limit range to the south (Fig. 1; Kelsall \& Telfer, 1974; Renecker \& Hudson, 1986; Karns, 1998; but see Crighton (2000) for new northern records to $67^{\circ} 31^{\prime} \mathrm{N}$ in Canada). Although there is information within reports from southeast Alaska (Klein, 1965; Alaska Department of Fish \& Game, 1973; MacDonald \& Cook, 1996), workers have not commented in depth on observed range expansion into coastal North America. We report here the recent arrival of moose to the west coast temperate rainforests of British Columbia (BC), Canada and speculate on the potential causes and consequences. We estimated current range of moose by noting observations of moose and their sign, and by identifying moose remains in wolf faeces. Further insight into distribution and timing of expansion was gained through traditional ecological knowledge (Huntington, 2000; Pierotti \& Wildcat, 2000; Turner et al., 2000; Usher, 2000), shared by coastal First Nations peoples during informal interviews.

\section{METHODS}

We collected interview and ecological data on the central and north coast of BC, an area comprising more than $60,000 \mathrm{~km}^{2}$ (Fig.1). Extensive fjords and tidal waters separate mainland landmasses and islands, which range in size from $<1 \mathrm{~km}^{2}$ to $>2200 \mathrm{~km}^{2}$. Inter-island and mainland-island distances range 


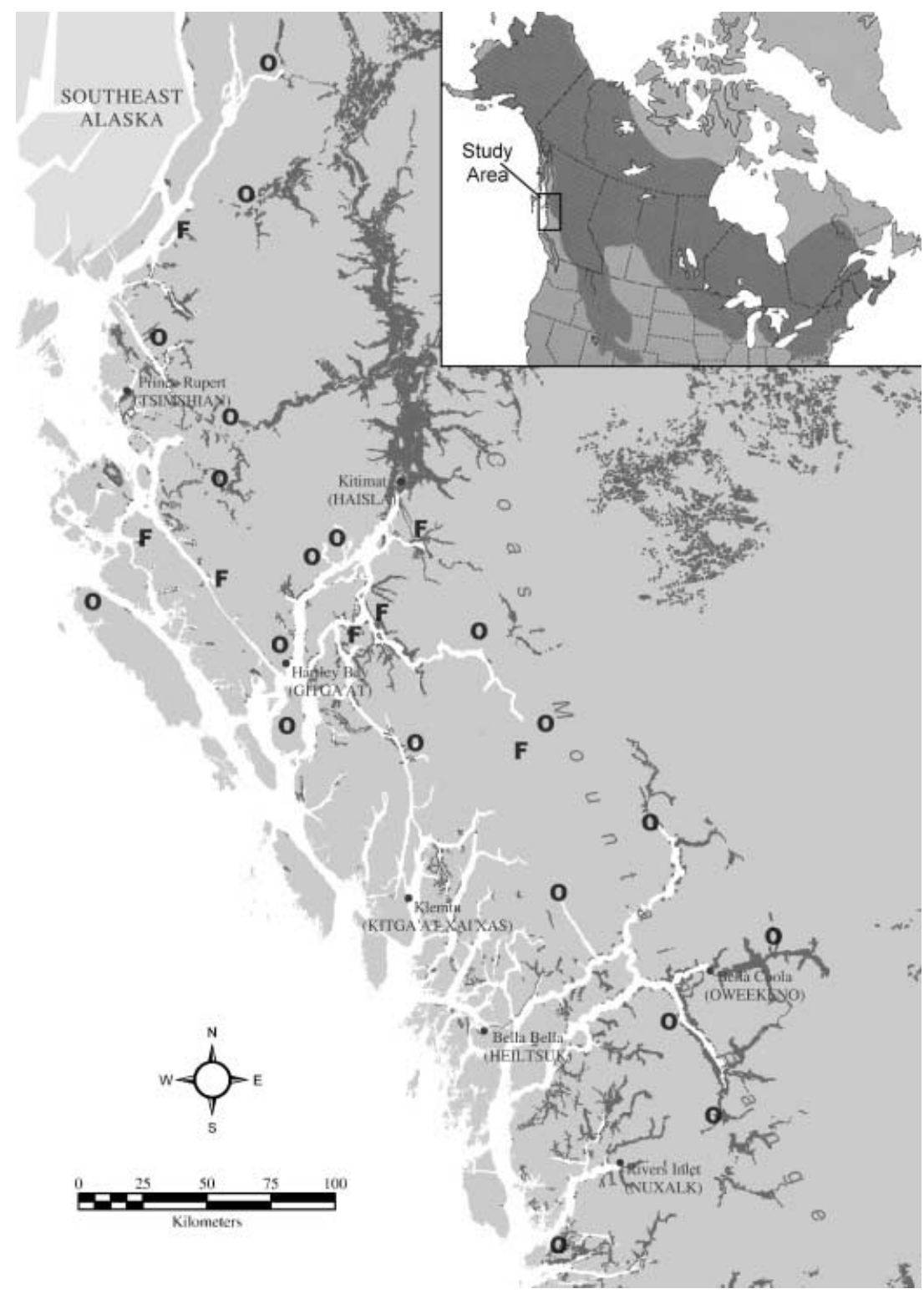

Figure 1 Study area on British Columbia's (BC's) coast. Shown are locations where moose or their sign are observed commonly by coastal First Nations peoples or by the authors during fieldwork $(\mathbf{O})$, and where moose remains have occurred in the faeces of wolves, Canis lupus (F) collected during summers 2000 and 2001 (Darimont et al., 2004). Note that, owing to limited interviews and fieldwork, data likely represent a subset of moose range on BC's coast. Dark grey shading indicates areas modified by logging. Coastal villages and associated First Nations groups from which interview data were derived are also shown. Geographic data in BC Albers projection. Inset shows moose distribution in North America in dark grey (from Karns, 1998). from several metres to approximately $13 \mathrm{~km}$. Most of the low-elevation forest is within the Coastal Western Hemlock biogeoclimatic zone (sensu Krajina, 1965), characterized by a wet and temperate climate. Annual precipitation exceeds $350 \mathrm{~cm}$ in most areas.

During early stages of ecological studies of wolves and their prey (Darimont \& Paquet, 2000, 2002), we conducted informal interviews with First Nation peoples (mostly elders; $n=7$ ), who constitute most of the human population in this remote region. We also interviewed naturalists $(n=2)$ with extensive experience on BC's coast, who have written on the area's flora and fauna (McAllister et al., 1997). Discussions varied but always included asking where interviewees commonly see moose and about their first observation of moose on the coast. Additionally, we noted locations of moose sign (tracks, pellets) and visual observations of animals during fieldwork $(n=32)$. Finally, we conducted an analysis of prey remains in wolf faeces $(n=595)$ collected along
BC's coast during the summers of 2000 and 2001 (Fig. 1; Darimont et al., 2004). We followed standard dietary analysis methods using dissecting microscopes with voucher hair specimens and dichotomous keys (Ciucci et al., 1996). Although wolves may deposit faeces with moose remains in areas far from where moose are killed, we consider this possible bias negligible given the spatial scale of the study area. For Fig. 1, we overlaid moose occurrence data on $\mathrm{BC}$ provincial base data using $\mathrm{BC}$ Albers projection in a Geographic Information System (ArcView 3.2, Environmental Systems Research Institute Inc.). A data layer showing areas modified by logging was obtained from the Sierra Club of British Columbia (http://bc.sierraclub.ca/).

\section{RESULTS AND DISCUSSION}

Moose are now widespread along the mainland of BC's coastal temperate rainforests and occur on at least three islands (Fig. 1). 
This distribution exceeds that described in recent BC government and museum publications, which suggest that moose are generally absent west of the Coast Mountain Range, except in some small localized areas along rivers and heads of inlets (Nagorsen, 1990; Shackleton, 1999; Blood, 2000). Data we report here may represent expansion since these publications. More likely, the discrepancy may reflect the paucity of field investigations conducted along the remote $\mathrm{BC}$ coast, coupled with the low density and elusive nature of moose. All interviews and field observations suggest that moose occur at low densities on the coast. Researchers in nearby southeast Alaska (Fig. 1) have noted moose in major mainland river valleys and on several nearby islands, and estimated arrival in the early 1900's (Klein, 1965; Alaska Department of Fish \& Game, 1973; MacDonald \& Cook, 1996).

Interviews were valuable in establishing that moose were absent on BC's coast in recent history and in estimating the timing of arrival. Moose are not known to be part of historical ceremonial tradition or subsistence use in all First Nation groups contacted. Cecil Paul, a Haisla elder, offered a representative statement regarding moose expansion, 'moose were not here or ever a part of stories when I was a child'. Records from European explorers, traders, and travellers also suggest that moose distribution to mid-nineteenth century did not include coastal BC, (Spalding, 1989). Interviewees indicated that range expansion first occurred in the mid 1900s. For example, Frank Hanuse of the Oweekeno Nation estimates the earliest arrival of moose in the 1940s, with sightings becoming more frequent in subsequent years.

Migration hypotheses, as well as independent genetic and palaeovegetative data, imply that moose could have occupied coastal British Columbia before maintained oral or written history. Bubenik (1998) speculated that moose may have migrated through and existed in glacial refugia of Alaska en route to the Canadian tundra from Siberia during the Wisconsinian glacial period. During the same time, vegetative and genetic data from other mammals suggest that similar refugia existed to the south on the continental shelf off the BC coast (Warner et al., 1982; Josenhans et al., 1993; Byun et al., 1997), which may also have supported moose. The persistence of Dawson Caribou (Rangifer tarandus dawsoni) on Haida Gwaii, coastal BC, from the early Holocene until the early 1900s (Cowan \& Guiguet, 1956; Byun et al., 2002) and the current widespread coexistence of moose and caribou in North America suggest that the coastal habitat of $\mathrm{BC}$ may have been suitable for moose at least during the early to mid-Holocene. After extensive inquiry, however, we did not find supporting archaeological evidence.

Habitat modification has been implicated as a factor in recent moose expansions in other areas of North America (Karns, 1998) and we suspect the same in western Canada. The timing coincides with the first large-scale logging of major mainland watersheds that bisect the Coast Mountain Range, which began during the early to mid 1900s (Drushka, 1992, 1998; Fig. 1). The new travel routes along roads and the availability of emergent vegetation post-logging would have facilitated an expanding moose population. Notably, most interviewees independently postulated a similar or identical hypothesis when asked why they believed moose have arrived on the coast. Alternatively, moose may have migrated south from coastal Alaska during the twentieth century. This is unlikely, however, given earlier accounts of moose presence only in localized areas near the Coast Mountain Range (Nagorsen, 1990; Shackleton, 1999; Blood, 2000).

We can only speculate on the possible ecological consequences of this immigration. Our wolf dietary data suggest that moose have already altered the historical wolf- and black-tailed deer (Odocoileus hemionus) association on the coast. Across a large study area, moose now represent nearly $10 \%$ of mammalian biomass consumed by wolves during spring and summer (Darimont et al., 2004). Likewise, all First Nation respondents indicate that moose are now (lightly) hunted for food. Notably, moose may influence parasite dynamics in deer. For example, moose are thought to be the most important hosts of winter ticks, Dermacentor albipictus, a parasite that also affects deer (Welch et al., 1991). Conversely, parasite-mediated competition with deer (e.g. Bogaczyk et al., 1993; Schmitz \& Nudds, 1994) or other biotic factors may limit moose densities or permanence on the coast. For example, un-manipulated coastal temperate rainforests contain vegetation communities and successional dynamics that do not fit the traditional definitions of moose habitat (Telfer, 1984). These ancient coastal forests, however, are being rapidly converted to tree farms by large-scale logging (Darimont \& Paquet, 2000, 2002; Moola et al., 2004), which offer extensive areas of new plant growth of variable age classes throughout the landscape over time. If the volume harvested and current logging practices continue, these anthropogenic changes will likely further facilitate moose presence and distribution on BC's coast.

\section{ACKNOWLEDGEMENTS}

This study took place in the Traditional Territories of the Gitga'at, Haisla, Heiltsuk, Kitasoo/Xai'Xais, Nuxalk, Oweekeno, and Tsimshian peoples, from whom we sought permission before research began. We thank interviewees for sharing their knowledge, we also thank the Raincoast Conservation Society for financial and logistical support, many colleagues for field assistance, and skippers Stephen Anstee, Brian Falconer, Jean-Marc Leguerrier, and Dave Lutz. We thank the Arcteryx Inc., Bullit Foundation, Defenders of Wildlife USA, McCaw Foundation, National Geographic Society, Mountain Equipment Co-op, Patagonia Inc., University of Montana Paquet Fund, Vancouver Foundation, Wilburforce Foundation, World Wildlife Fund, and private donors who kindly provided funding. While preparing the manuscript, CTD was supported by a Natural Sciences and Engineering Research Council (NSERC) Industrial Postgraduate Scholarship and TER by a NSERC operating grant (NRC2354) and funds from the David Suzuki Foundation. We thank the Sierra Club of BC for logging data and Katrina Bennett for GIS support, as well as B. D. Patterson and an anonymous reviewer for thoughtful comments that improved the manuscript.

\section{REFERENCES}

Alaska Department of Fish and Game. (1973) Alaska's wildlife and habitat. Anchorage, Alaska. 
Blood, D. (2000) Moose in British Columbi: ecology, conservation, and management. British Columbia Ministry of Wildlife, Lands, and Parks, Victoria, British Columbia.

Bogaczyk, B.A., Krohn, W.B. \& Gibbs, H.C. (1993) Factors affecting Parelaphostrongylus tenuis in white-tailed deer (Odocoileus virginianus) from Maine. Journal of Wildlife Disease, 29, 266272.

Bubenik, A.B. (1998) Evolution, taxonomy and morphology. Ecology and management of the North American moose (ed. by A. Franzmann and C. Schwartz), pp. 77-123. Smithsonian Institution Press, Washington, DC.

Byun, A.S., Koop, B. \& Reimchen, T.E. (1997) North American black bear mtDNA phylogeography: implications for morphology and the Haida Gwaii refugium controversy. Evolution, 51, 1647-1653.

Byun, A.S., Koop, B. \& Reimchen, T.E. (2002) Evolution of Dawson Caribou. Canadian Journal of Zoology, 80, 956-960.

Ciucci, P., Boitani, L., Pelliccioni, E.R., Rocco, M. \& Guy, I. (1996) A comparison of scat-analysis methods to assess the diet of the wolf Canis lupus. Wildlife Biology, 2, 37-48.

Cowan, I.McT. \& Guiget, C.J. (1956) The mammals of British Columbia. British Columbia Provincial Museum, Handbook no. 11, Victoria, British Columbia.

Crighton, V. (2000) Are you moose wise? The Moose Call, 11, 22.

Darimont, C.T. \& Paquet, P.C. (2000) The grey wolves (Canis lupus) of British Columbia's coastal rainforests: findings from year 2000 pilot study and conservation assessment. Prepared for the Raincoast Conservation Society, Victoria, British Columbia. Available on www.raincoast.org.

Darimont, C.T. \& Paquet, P.C. (2002) The Grey Wolves, Canis lupus, of British Columbia's Central and North coast: distribution and conservation assessment. Canadian Field-Naturalist, 116, 416-422.

Darimont, C.T., Price, M.H., Winchester, N.H.H., GordonWalker, J. \& Paquet, P.C. (2004) Predators in natural fragments: foraging ecology of wolves in British Columbia's central and north coast archipelago. Journal of Biogeography, 31, 1867-1877.

Drushka, K. (1992) Working in the woods: a history of logging on the west coast. Harbour Publishing, Madeira Park, British Columbia.

Drushka, K. (1998) Tie hackers to timber harvesters: the history of logging in British Columbia's interior. Harbour Publishing, Madeira Park, British Columbia.

Hundertmark, K.J., Shields, G.F., Udina, I.G., Bowyer, R.T., Danilkin, A.A. \& Schwartz, C.C. (2002) Mitochondrial phylogeography of moose (Alces alces): Late Pleistocene divergence and population expansion, Molecular Phylogenetis and Evolution, 22, 375-387.

Huntington, H.P. (2000) Using traditional ecological knowledge in science: methods and applications. Ecological Applications, 10, 1270-1274.

Josenhans, H.W., Barrie, J.V., Conway, K.W., Patterson, T., Mathewes, R. \& Woodsworth, G.J. (1993) Surficial geology of the Queen Charlotte Basin: evidence of submerged proglacial lakes at $170 \mathrm{~m}$ on the continental shelf of western Canada.
Geological Survey of Canada, Current Research Paper, 93-1A, 119-127.

Karns, P.D. (1998) Population distribution, density, and trends. Ecology and management of the North American moose (ed. by A. Franzmann and C. Schwartz), pp. 125-139. Smithsonian Institution Press, Washington, DC.

Kelsall, J.P. \& Telfer, E.S. (1974) Biogeography of moose with particular reference to western North America. Naturaliste Canadien, 101, 117-130.

Klein, D.R. (1965) Postglacial distribution patterns of mammals in the southern coastal regions of Alaska. Arctic, 18, 7-20.

Krajina, V.J. (1965) Biogeoclimatic zones and classification of British Columbia. Ecology of Western North America, 1, 1-17.

Kurtén, B. \& Anderson, A. (1980) Pleistocene mammals of North America. Columbia University Press, New York.

Laliberte, A.S. \& Ripple, W.J. (2004) Range contractions of North American carnivores and ungulates. Bioscience, 54, 123-138.

Lister, A.M. (1993) Evolution of mammoths and moose: the Holocene perspective. Morphological change in Quaternary mammals of North America (ed. by R.A. Martin and A.D. Barnosky), pp. 178-204. Cambridge university Press, Cambridge.

Lyons, K.S. (2003) A quantitative assessment of the range shifts of Pleistocene mammals. Journal of Mammology, 83, 385-402.

MacDonald, S.O. \& Cook, J.A. (1996) The land mammal fauna of Southeast Alaska. Canadian Field Naturalist, 110, 571-598.

McAllister, I., McAllister, K. \& Young, C. (1997) The great bear rainforest: Canada's forgotten coast. Harbour Publishing, Madeira Park, British Columbia.

Moola, A.M., Martin, V., Wareham, B., Calot, J., Burda, C. \& Grames, P. 2004. The coastal temporate rainforests of Canada: the need for Ecosystem-Based Management, Biodiversity, 5, 9-15.

Nagorsen, D.W. (1990) The mammals of British Columbia: a taxonomic catalogue. Memoir Number 4. Royal British Columbia Museum, Victoria, British Columbia.

Oden, J.D., Poff, N.L., Douglas, M.R., Douglas, M.E. \& Fausch, K.D. (2004) Ecological and evolutionary consequences of biotic homogenizations. Trends in Ecology and Evolution, 19, 18-24.

Parmesan, C. \& Yohe, G. (2003) A globally coherent fingerprint of climate change impacts across natural systems. Nature, 421, 37-42.

Pierotti, R. \& Wildcat, D. (2000) Traditional ecological knowledge: the third alternative. Ecological Applications, 10, 13331340.

Renecker, L.A. \& Hudson, R.J. (1986) Seasonal energy expenditures and thermoregulatory responses of moose. Canadian Journal of Zoology, 64, 322-327.

Schmitz, O.J. \& Nudds, T.D. (1994) Parasite-mediated competition in deer and moose: how strong is the effect of meningeal worm on moose? Ecological Applications, 4, 91-103.

Shackleton, D. (1999) Hoofed mammals of British Columbia. University of British Columbia Press, Vancouver, British Columbia.

Sih, A., Jonsson, B.G. \& Luikart, G. (2000) Habitat loss: ecological, evolutionary and genetic consequences. Trends in Ecology and Evolution, 15, 132-134. 
Spalding, D.J. (1989) The early history of moose (Alces Alces): distribution and relative abundance in British Columbia. Contributions to Natural Science, Number 11. Royal British Columbia Museum, Victoria, British Columbia.

Telfer, E.S. (1984) Circumpolar distribution and habitat requirements of moose (Alces Alces). Northern ecology and resource management (ed. by R. Olsen, R. Hastings and F. Gendes), pp. 145-182. University of Alberta Press, Edmonton, Alberta.

Turner, N.J., Ignace, M.B. \& Ignace, R. (2000) Traditional Ecological Knowledge and Wisdom of aboriginal peoples in British Columbia. Ecological Applications, 10, 1275-1287.
Usher, P.J. (2000) Traditional ecological knowledge in environmental assessment and management. Arctic, 53, 183-193.

Vermeij, G.J. (1991) When biotas meet: understanding biotic interchange. Science, 253, 1099-1104.

Warner, B.G., Mathewes, R.W. \& Clague, J.C. (1982) Ice-free conditions on the Queen Charlotte Islands, British Columbia, at the height of late Wisconsin glaciation. Science, 218, 675-677.

Welch, D.A., Samuel, W.M. \& Wilke, C.J. (1991) Suitability of moose, elk, mule deer, and white-tailed deer as hosts for winter ticks, Dermacentor albipictus. Canadian Journal of Zoology, 69, 2300-2305. 